\title{
Detection and assessment of antibodies against bovine viral diarrhea virus in swine serum using the virus neutralization assay
}

\author{
Avaliação dos títulos de anticorpos obtidos no diagnóstico de infecções pelo BVDV em suínos \\ utilizando o teste de virusneutralização
}

\section{Henrique Meiroz de Souza Almeida ${ }^{1}$, Igor Renan Honorato Gatto ${ }^{1}$, Karla Alvarenga Nascimento ${ }^{1}$, Marina Lopes Mechler Dreibi ${ }^{1}$, Samir Issa Samara ${ }^{1}$, Luís Guilherme Oliveira ${ }^{1}$}

\begin{abstract}
The Bovine viral diarrhea virus (BVDV) infections in swine are an important issue to the swine industry due to cross-reaction in serological exams, with the Classical swine fever virus (CSFV) resulting in false-positives. This paper focused on reporting and comparing antibody titers detected in swine serum samples using the virus neutralization assay (VN). To this, 3,084 swine serum samples of 115 swine herds of eight Brazilian states were tested using the VN with BVDV-1 strain Singer and BVDV-2 VS253. Anti-BVDV antibodies were detected in 133 samples (4.31\%), 75 (2.43\%) were positive when using the BVDV-1 in the assay and $58(1.88 \%)$ were reagent when using the BVDV-2. At herd level, $44.35 \%$ (51/115; CI 95\%: 35.27-53.43\%) had at least one positive animal regardless the species of the virus. The results show that low antibody titer were significantly more frequent than the high ones. Antigenic diversity among the strains used in the VN and the one circulating in swine, and vaccine contamination with BVDV could be involved in the high frequency of low titers. In conclusion, antibodies anti-BVDV were detected in swine of different Brazilian regions. Animal health authorities should be aware of the risk of false positive results to CSF.
\end{abstract}

Keywords: Virus neutralization, Pestivirus, Swine, Antibodies

Resumo: As infecções pelo vírus da Diarreia Viral Bovina (BVDV) em suínos se apresentam muito problemáticas para a suinocultura devido aos anticorpos anti-BVDV poderem apresentar reação cruzada em testes sorológicos no diagnóstico de Peste Suína Clássica, resultando em falsos positivos. Informações sobre provas laboratoriais para diagnóstico de infecções pelo BVDV em suínos são muitos escassas na literatura científica. Sendo assim, este estudo objetivou relatar e comparar os títulos de anticorpos detectados pela reação de virusneutralização (VN) para o BVDV em amostras de soro suíno. Para isto, 3084 amostras de soro sanguíneo de 115 rebanhos suínos provenientes de oito estado brasileiros foram submetidas à VN utilizando-se os genótipos BVDV-1 e BVDV-2. Anticorpos foram detectados em 134 amostras (4,34\%), $76(2,46 \%)$ reagentes ao genótipo 1 e $58(1,88 \%)$ ao genótipo 2 do vírus. Resultados indicam a predominância de títulos baixos para BVDV em suínos. Diferenças antigênicas entre as estirpes circulantes e as utilizadas na VN junto com contaminação vacinal pelo BVDV podem estar relacionados com a alta frequência de baixos títulos. Anticorpos anti-BVDV foram detectados em amostras de soro suíno de diferentes regiões do Brasil. Esses dados são um alerta à sanidade animal sobre a possibilidade de resultados falso-positivo em testes para PSC.

\section{Palavras-chave: Virusneutralização, Pestivirus, Suíno, Anticorpos}

Corresponding author: luis.guilherme@unesp.br

Recebido em 7.12.2018. Aceito em 30.3.2019

http://dx.doi.org/10.5935/1981-2965.20190001 
Dados obtidos em projeto de pesquisa conduzido por estudantes de pós-graduação da Universidade Estadual Paulista - FCAV Unesp

${ }^{1}$ School of Agricultural and Veterinarian Sciences, São Paulo State University (Unesp). Via de acesso Prof. Paulo Castellane, s/n, CEP 14884-900, Jaboticabal, São Paulo, Brazil.

Henrique Meiroz de Souza Almeida - Graduate Program in Veterinary Medicine, School of Agricultural and Veterinarian Sciences (FCAV), São Paulo State University (Unesp).henri_almeida2003@yahoo.com.br

Igor Renan Honorato Gatto - Graduate Program in Veterinary Medicine, School of Agricultural and Veterinarian Sciences (FCAV), São Paulo State University (Unesp) igatto_10@ hotmail.com

Karla Alvarenga Nascimento - Graduate Program in Veterinary Medicine, School of Agricultural and Veterinarian Sciences (FCAV), São Paulo State University (Unesp).karlanascimentovet@ yahoo.com.br Marina Lopes Mechler Dreibi - Graduate Program in Veterinary Medicine, School of Agricultural and Veterinarian Sciences (FCAV), São Paulo State University (Unesp).mlopesvet@ gmail.com

Samir Issa Samara - Department of Preventive Veterinary Medicine, School of Agricultural and Veterinarian Sciences (FCAV), São Paulo State University (Unesp). samara@ fcav.unesp.br

Luís Guilherme Oliveira - Department of Veterinary Clinic and Surgery, School of Agricultural and Veterinarian Sciences (FCAV), São Paulo State University (Unesp). Via de Acesso Prof. Paulo Donato Castellane s/n, Jaboticabal, SP 14884-900, Brazil. luis.guilherme@ unesp.br

\section{Introduction}

Among the inter-species transmission of the agents of the Pestivirus genus, little is known about Bovine viral diarrhea virus (BVDV) infections in pigs. These infections can be very problematic since infected swine present clinical signs resembling Classical swine fever (CSF), which is a disease of compulsory notification that has major impacts in the swine industry (WENSVOORT et al., 1989; MOENNIG \& LIESS, 1990; BRAZIL, 2004). The first report of the isolation of a ruminant Pestivirus from naturally infected pigs was in the year of 1973 (FERNELIUS et al., 1973).

Despite BVDV infections in swine were at the beginning considered asymptomatic, some reports have recently associated reproductive disorders in sows, fever and diarrhea, to such infections
(TAO et al., 2013). Thus, in pregnant sows, transplacentary infection might happen resulting in abortion, stillbirth piglets, birth of weak piglets, birth defects in piglets and even the occurrence of persistently infected piglets (BECHER et al., 2003; RIDPATH, 2010). Epidemiological findings place cattle as the main infection source of BVDV to pigs (RIDPATH, 2010). The main transmission route is the use of infected cattle's milk or derivatives in the swine feed (Alpay \& Yesilbag, 2015) and through fomites (CARBREY et al., 1976).

Due to the close antigenic relation with the Classical swine fever virus (CSFV), the presence of anti-BVDV antibodies in swine serum prevented the infection by CSFV in the animals (WIERINGA-JELSMA et al., 2006). Thus, it has been reported that anti-BVDV 
antibodies can interfere in serological surveys of CSFV due to antibody crossreactions (JENSEN, 1981).

The virus neutralization assay (VN) is a diagnostic test based on the identification and quantification of antibodies produced against the $\mathrm{E}_{2}$ glycoprotein of the viral envelope (SANDVIK, 2005). This assay is considered the standard technique for diagnosing BVDV and CSFV (OIE, 2016) due to several advantages it has, such as: capacity of identifying and quantifying antibodies, the possibility of using serum of any species and the possibility of using different genotypes/subgenotype of BVDV as the antigen, which increases the sensitivity of the test (DUBOVI, 2013).

Data regarding the use of $\mathrm{VN}$ for the diagnostic of BVDV infection in swine is very scarce in the scientific literature. This research focused on reporting the results obtained by using the $\mathrm{VN}$ for the detection of anti-BVDV antibodies in swine serum.

\section{Material and methods}

Sample characterization - All samples used in this study are part of the samples bank of the Laboratory of Swine Health Research (UNESP Câmpus Jaboticabal). A set of 3084 swine serum samples, from 115 different herds (39 farrow-to-finish industrial herds and 76 herds from nontechnified farms) were tested using the VN in order to detect the presence of antiBVDV antibodies.

All samples were part of The samples were from eight Brazilian states: Goiás, Mato Grosso do Sul, Mato Grosso, Paraná, Rio Grande do Sul, Santa Catarina, Rio Grande do Norte and São Paulo, and were collected during the years of 2013 and 2014. Table 1 presents the origin per state of the samples used.

Table 1. Quantity and origin of samples, collected during 2013 and 2014, per state

\begin{tabular}{lc}
\hline State & Number of samples \\
\hline Mato Grosso & 50 \\
Mato Grosso do Sul & 140 \\
Goiás & 91 \\
São Paulo & 1317 \\
Paraná & 418 \\
Santa Catarina & 558 \\
Rio Grande do Sul & 98 \\
Rio Grande do Norte & 412 \\
\hline Total & $\mathbf{3 0 8 4}$ \\
\hline
\end{tabular}

Virus neutralization assay (VN) 
In order to detect anti-BVDV-1 and anti-BVDV-2 antibodies a VN was performed according to the protocol described in the Manual of Diagnostic Tests and Vaccines for Terrestrial Animals (OIE, 2016). The cell line used was the MDBK (Madine Darby Bovine Kidney), and the samples were tested separately using two different cytopathic strains as the standard virus: Singer (BVDV-1) and VS253 (BVDV-2), in a 100 TCID $_{50}$ (" $50 \%$ Tissue culture infective dose") concentration. Each serum was tested in duplicate subjected to two fold serial dilutions starting at 1:10 until 1:5120. The results obtained in the $\mathrm{VN}$ were either positive or negative. The positive samples were those in which occurred total neutralization of the $100 \mathrm{TCID}_{50}$ in a dilution higher or equal 1:10. The final antibody titer considered was the reciprocal of the highest dilution in which occurred neutralization of the viral dose.

A differential diagnosis for CSF was performed in all the $\mathrm{VN}$ positive samples at an official laboratory (Instituto Biológico - APTA/SAA-SP) in order to avoid the possibility of cross-reaction with anti-CSF antibodies. To this, an Enzyme Linked Immunosorbent Assay - ELISA ac, PRIONICS $^{\circledR}$, was used according to the
Brazilian animal health legislation (Brazil, 2004).

Data Analysis- The antibody titer results was obtained by the geometric mean of the duplicates results. In order to describe the results and frequency of each titer occurrence it was used descriptive statistics.

The $95 \%$ confidence intervals (CI $95 \%$ ) for frequency values lower than $5 \%$ were calculated using Wilson's method. For proportions higher than $5 \%$, it was used the standard formula (THRUSFIELD, 2010).

The occurrence of significant differences between two titers frequencies was detected by the absence of superposition of the CI $95 \%$ of the values.

Ethics comitee approval- This research was approved by Ethics Comitee for Animal Experimentation (CEUA) of the School of Agricultural and Veterinarian Sciences of São Paulo - FCAV/Unesp, Jaboticabal - SP, under the protocol number 07998/14. The authorization for the CSF Elisa was granted by the Brazilian Ministry of Agriculture, Livestock and Food under the number 214/2015 SSA/DDA/SFA-SP.

\section{Results}

In total, out of the 3.084 swine 
serum samples tested by $\mathrm{VN}, 4.31 \%$ (134; C.I. $95 \%: 3.68 \%-5.12 \%$ ) were reagent to at least one of BVDV species (1 and 2), and none of those were CSF positive in the ELISA. When separating by species, $2.46 \%$ (76; CI 95\%:1.97\%-3.07\%) were BVDV-1 positive while $1.88 \%$ (58; CI 95\%: $1.46 \%-2.42 \%)$ were BVDV-2 positive. The frequency of titer obtained and its respective confidence interval are shown in Table 2. The most frequent titer for both species of BVDV was 10, obtained in $36.84 \%$ of BVDV-1 tested samples and 68.96 of samples when using BVDV-2. For a better visualization, the titers values were converted in base 10 logarithmic and are shown in the graph bellow (Figure 1).

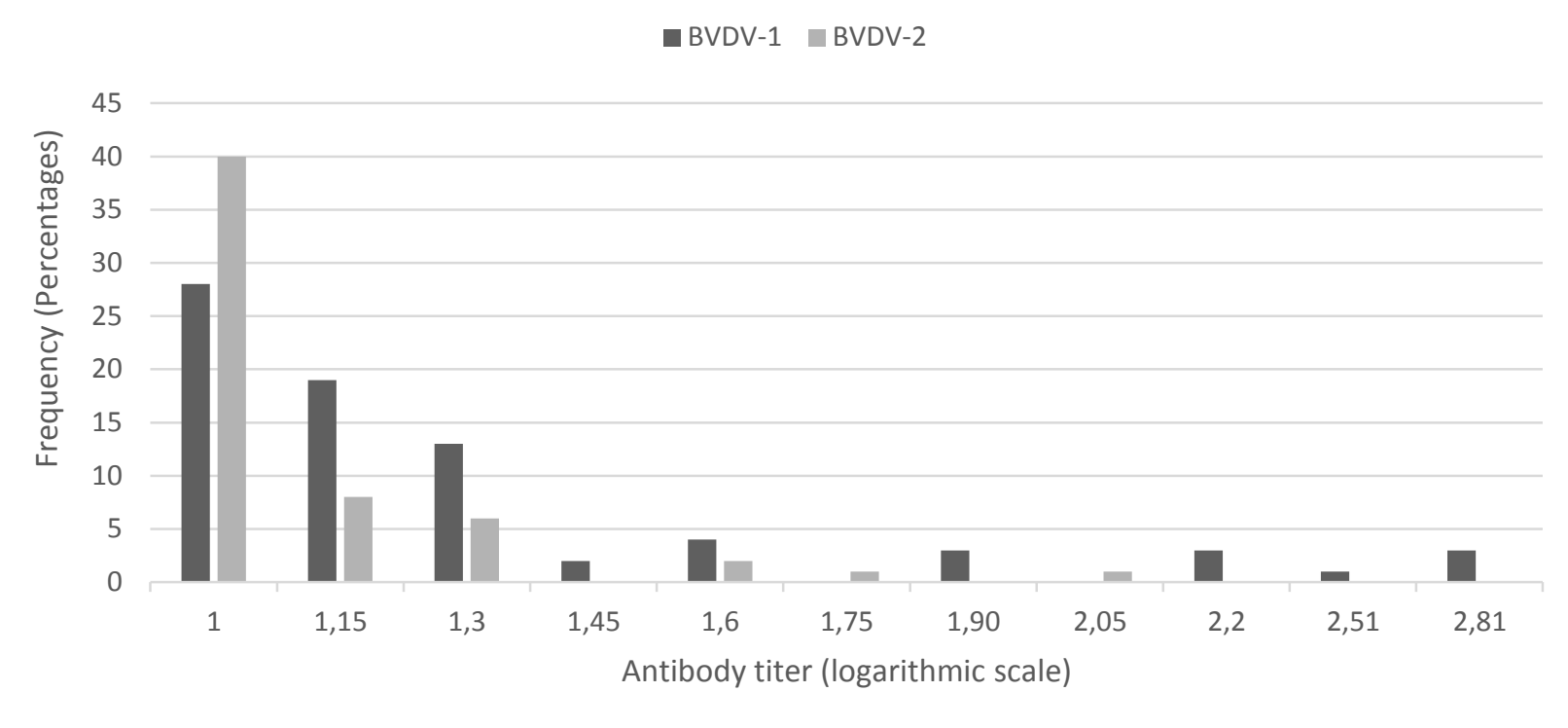

Figure 1. Bar graph of the obtained titers frequencies in the VN, using BVDV-1 Singer and BVDV-2 VS253. The titer values are shown in base 10 logarithmic scale, in which: $1=10 ; 1.15=14.14 ; 1.3=20 ; 1.45=28.28 ; 1.6=40 ; 1.75=56.56 ; 1.90=80 ; 2.05=$ $113.13 ; 2.2=160 ; 2.51=320$ e $2.81=640$.

Regarding to the results obtained when using the BVDV-1 Singer strain, the frequency of the titers 10 and 14.14 were significantly higher than other titers frequency, at a 95\% confidence level. When using the BVDV-2 strain VS253, only the frequency of titer 10 was significantly higher from all the other frequencies at a $95 \%$ confidence level.

At herd level, 44.35\% (51/115; CI 95\%: $35.27-53.43 \%$ ) had at least one 
positive animal to BVDV regardless the species of the virus.

Table 2. Frequencies of titers obtained in the VN using strains BVDV-1 Singer and BVDV-2 Vs253 and respective 95\% Confidence Interval

\begin{tabular}{|c|c|c|c|c|c|c|c|}
\hline Strain & $\begin{array}{l}\text { Mean } \\
\text { Titer }\end{array}$ & Frequency & $\begin{array}{l}\text { C.I. } \\
95 \%\end{array}$ & Strain & $\begin{array}{l}\text { Mean } \\
\text { Titer }\end{array}$ & $\begin{array}{c}\text { Frequen } \\
\text { cy }\end{array}$ & C.I. $95 \%$ \\
\hline \multirow{9}{*}{$\begin{array}{c}\text { BVDV- } \\
1\end{array}$} & 10 & $36.84 \%{ }^{\mathrm{a}}$ & $\begin{array}{l}25.99 \%- \\
47.68 \%\end{array}$ & & 10 & $68.96 \%{ }^{\mathrm{a}}$ & $\begin{array}{l}57.05 \%- \\
80.07 \%\end{array}$ \\
\hline & 14.14 & $25.33 \%^{\mathrm{ab}}$ & $\begin{array}{l}15.55 \%- \\
35.10 \%\end{array}$ & & 14.14 & $13.79 \% \mathrm{~b}$ & $\begin{array}{l}4.91 \%- \\
22.66 \%\end{array}$ \\
\hline & 20 & $17.10 \%^{\mathrm{bc}}$ & $\begin{array}{l}8.64 \%- \\
25.56 \%\end{array}$ & & 20 & $10.34 \%^{\mathrm{b}}$ & $\begin{array}{l}2.05 \%- \\
18.18 \%\end{array}$ \\
\hline & 28.28 & $2.63 \%{ }^{\mathrm{bcd}}$ & $\begin{array}{l}0.72 \%- \\
9.09 \%\end{array}$ & $\begin{array}{c}\text { BVDV- } \\
2\end{array}$ & 40 & $3.44 \% \mathrm{~b}$ & $\begin{array}{l}0.95 \%- \\
11.73 \%\end{array}$ \\
\hline & 40 & $5.26 \%{ }^{\mathrm{bcd}}$ & $\begin{array}{l}0.24 \%- \\
10.28 \%\end{array}$ & & 56.56 & $1.72 \%^{\mathrm{b}}$ & $\begin{array}{l}0.30 \%- \\
9.14 \%\end{array}$ \\
\hline & 80 & $3.95 \%{ }^{\mathrm{cd}}$ & $\begin{array}{l}1.35 \%- \\
10.97 \%\end{array}$ & & 80 & $1.72 \% \mathrm{~b}$ & $\begin{array}{c}0.30 \%- \\
9.14 \%\end{array}$ \\
\hline & 160 & $3.95 \% \mathrm{~cd}$ & $\begin{array}{l}1.35 \%- \\
10.97 \%\end{array}$ & & 160 & $0 \%$ & - \\
\hline & 320 & $1.31 \%{ }^{\mathrm{d}}$ & $\begin{array}{c}0.23 \%- \\
7.08 \%\end{array}$ & & 320 & $0 \%$ & - \\
\hline & 640 & $3.95 \%$ cd & $\begin{array}{l}1.35 \%- \\
10.97 \%\end{array}$ & & 640 & $0 \%$ & - \\
\hline
\end{tabular}




\section{Discussion}

Anti-BVDV antibodies were detected in 4.31\% (134 95\%CI; C.I. 95\%: $3.68 \%-5.12 \%$ ) of the samples in this study and in $44.35 \%$ (51/115; CI 95\%: $35.27-$ $53.43 \%$ ) of farms sampled. The presence of antibodies anti-BVDV in swine serum is a concerning finding, since the great antigenic similarity between the CSFV and BVDV increases the odds of serological cross-reaction leading to false-positive results in official CSF diagnostic tests. Serological cross-reactions have been pointed out as a major concern for epidemiological surveys and even CSF eradication (LOEFFEN et al., 2009; Tao et al., 2013).

According to De Smit et al. (1999), false negative results due to serological cross reaction issues, requires secondary tests in order to achieve and accurate true status of the herd, leading to bigger time lapse in the decision making process, what could facilitate the spread of the disease to larger areas and consequently bigger economic loss. Thus, during a CSF outbreak in 1990, the presence of antiBVDV antibodies in the swine herd serum hindered the diagnosis of positive animals due to the high amount of false positive results which demanded second tests (DE SMIT et al., 1999).
Even though in this research, none of the positive samples presented crossreactions apparently in the CSF ELISA, the risk of anti-BVDV antibodies resulting in false positive in CSF diagnostic tests has been reported in the scientific literature. Schroeder et al. (2012) tested the seven most used ELISA kits for diagnosing CSF and concluded that three brands could poorly differentiate CSFV induced antibodies than BVDV induced ones. Due to great economic impact of $\mathrm{CSF}$ outbreaks, a precise and accurate official diagnostic test is required, in order to avoid great losses to the country's swine industry (WENSVOORT et al., 1990). This way, knowing the prevalence of BVDV infection in swineherds could be a useful information.

Regarding antibody titers found for BVDV in swine serum by this research were low, regardless the viral species used in the $\mathrm{VN}$, when compared to previous scientific reports. Loeffen et al. (2009), using the BVDV-1 strain Osloss, detected eight positive swine samples with titers ranging from 15 to 3,840 , and when using the strain NADL, five samples were positive with titers ranging from 30 to 160 . Taking into account that the swine is an atypical hosts for BVDV (Terpstra \& Wensvoort, 1988), it is possible that the 
low number of positive samples and the low antibody titers found could be related to a greater difficulty that this virus might have to infect the swine host. Consequently, the animal's immune system would quell the virus more easily, resulting in a higher frequency of low antibodies titers. On the other hand, further studies are required in order to confirm this information since the dynamics of the infection of BVDV in non-cattle hosts still not well-understood.

Thus, there are reports of BVDV contaminating cell cultures of several animal species in the literature, mainly due to the use of BVDV contaminated bovine serum or calf fetal serum (LEVINGS \& WESSMAN, 1991). Bolin et al. (1994) showed that out of 41 American Type Culture Collection (ATCC) cell lines 13 were contaminated with BVDV. The use of contaminated cell cultures to produce vaccine can result in contaminated vaccines, which may cause seroconversion or even diseases in vaccinated animals (LEVINGS \& WESSMAN, 1991). Seroconversion and BVDV infection in swine due to the use of contaminated vaccines has already been pointed as one possible transmission route and a risk factor for this cross-infection (TAO et al., 2013).
The antibodies found in swine serum in this research could be resulting of BVDV contamination in vaccines, leading the animals to seroconvert and present low titers of antibodies. However, there are no data about the vaccination status of the animals tested in this research. This idea might be enhanced due to the fact that, most of the producing farms have been adopting biosecurity measures, which have probably reduced the contact between pigs and ruminants, the main infection source (RIDPATH, 2010). The adoption of biosecurity measures was associated with the low prevalence of BVDV infection in swine (Loeffen et al., 2009; O'Sullivan et al., 2011), mainly due to adoption of only one animal species rearing, consequently reducing the interspecies contact and vaccinating animals more frequently.

Preliminary studies with BVDV experimental infection in swine in Brazil, detected seroconversion at 16th day post infection and viral excretion occurred only at day 17th (Santos et al., 2015), showing that in experimental situations, the swine did get infected and produced a measurable antibody response. An older report also showed seroconversion around day 15th post infection (STEWART et al., 1971). However, around day 28 post infection it was not possible to detect the virus in nasal 
and rectum swabs and organs fragments, in experimentally infected animals (PHILIP \& DARBYSHIRE, 1972).

One of the tested samples was reagent to both species used of the virus, presenting 640 titer when using the BVDV1 strain Singer and titer 80 when using BVDV-2 VS253. This fact could be related to cross reaction among BVDV species and even among members of the Pestivirus genus, which have being reported by several researches in the scientific literature (WENSVOORT et al., 1989; RIDPATH, 2010; VAN RIJN, 2007; DE SMIT et al., 1999).

Usually in cases of serological cross-reaction, the titers obtained are different for the species tested. In such cases, the antibody difference can reach a 128 times higher value for the homologous species when compared to titer obtained with the heterologous species (JELSMA et al., 2013). The authors considered this sample as positive for BVDV-1, since when using it as the standard virus in the $\mathrm{VN}$, the obtained titer was eight times higher than the titer obtained when using the BVDV-2.

On the other hand, members of the Pestivirus genus have great ability to mutate, resulting in high antigenic and genetic variability even inside the same species (RIBEIRO, 2009). When it comes to the BVDV, antigenic differences between the strains used in laboratory and circulating strains in the nature interferes or even alter in the quality of indirect laboratorial results (BOOTH et al., 2013).

Low antigenic similarity among BVDV species and strains in samples from different geographical sites have already been in the literature (JELSMA et al., 2013). Ribeiro (2009) showed that when using in the VN the strain IBSP-1020 (BVDV-2) isolated in Brazil, raised the sensitivity of the test consequently detecting more positive animals and higher mean antibody titers compared to the $\mathrm{VN}$ using the strain VS253 (BVDV-2) isolated in the USA and used in this research. However, this research only tested bovine serum samples and in order to extrapolate to swine serum samples a more focused study is necessary.

This fact could explain the majority of low titers (Table 2) observed in the VN performed in this research, since the strains used were isolated in North America and can possibly be antigenically different from the strains circulating in Brazil as Flores et al. (2002) (Alpay \& Yesilbag, 2015) showed it when compared BVDV 
strains from different origins.

Moreover, serological assays detected, in bovine serum, antibody titers 128 times higher when using a local strain as the antigen compared testes using an alien BVDV strain (FLORES et al., 2002). The antigenic difference between BVDV strains of different geographical regions could be involved in the high frequency of low titers found in the $\mathrm{VN}$ in this research, Flores et al. (2005) suggested that in order to achieve better results with bovine samples one must use local BVDV isolates of both species in the $\mathrm{VN}$ assay.

It is very likely that the same should be applied when using swine serum as well however further studies are necessary using pig's serum and local BVDV circulating strains, in order to have a clearer insight of how it could affect the diagnostic of the disease in swine. Despite the existence of limitations regarding the viral strain used, the VN still the best diagnostic test for Bovine viral diarrhea in cattle and swine, since it allows detecting and quantifying antibodies for several different species (DUBOVI, 2013).

The genomic differences among strains could consequently imply in antigenic differences between the strains circulating in non-cattle hosts from the ones of cattle like Singer and VS253. However, little is known about how much BVDV strains from non-cattle hosts genetically evolve and varies (FLORES et al., 2005). Thus, since the strains used in this research were isolated from bovines, it is also possible that it could be antigenically divergent of strains circulating in swineherds. Xu et al. (2006) demonstrated that the full genome sequence of swine BVDV strain ZM-95 genomic similarity with the bovine's strains ranged from $60.4 \%$ thru $76.7 \%$, while it presented approximately $83 \%$ of similarity with strain SD-0803, which is another swine BVDV strain (DENG et al., 2014).

The possibility that the antibodies detected in this study were induced by CSFV infection in the swine was discarded, since most of the samples came from the CSF-free (OIE, 2016) and Border disease is exotic in Brazil. Thus, all positive samples in the VN were ELISA tested for CSF and were negative. Even though recently there was the detection of a novel Pestivirus agent associated with the congenital tremor disease (Arruda et al., 2016) a condition that is also present in Brazil, no data about antibody crossreactions with anti-BVDV antibodies or 
anti-CSFV has been reported so far.

\section{Conclusion}

We have detected the presence of anti-BVDV antibodies in swine serum from different CSF-free regions of Brazil, mostly in low titers (10), this should serve as a warning for animal health authorities for the possible false-positive CSF results. Regarding to the VN, using a virus strain antigenically similar the one circulating in the region or possibly more adapted to swine could enhance the test's accuracy, since the use of heterologous strain can interfere in the detection power of the test.

\section{Acknowledgements}

The authors would like to acknowledge the São Paulo Research Foundation (FAPESP) for financial support provided by grant \#2014/13590-3.

\section{References}

1.ALPAY, G., YESILBAG, K. Serological relationships among subgroups in Bovine Viral Dirrhoea Virus genotype 1 (BVDV1). Veterinary Microbiology, v.175, n.1, p.1-6, 2015.

2. ARRUDA, B.L., ARRUDA, P.H., MAGSTADT, D.R., SCHWARTZ, K.J., DOHLMAN, T.,SCHLEINING, J.A.. Identification of a divergent lineage porcine pestivirus in nursing piglets with congenital tremors and reproduction of disease following experimental inoculation. PlosOne, v.11, n.2, p.1-12, 2016.

3. BECHER, P., RAMIREZ, R.A., ORLICH, M., ROSALES, S.C., KÖNIG, M., SCHWEIZER, M. Genetic and antigenic characterization of novel pestivirus genotypes: implications for classification. Virology, v.311, n.1, p.96104, 2003.

4. BOLIN, S.R., RIDPATH, J.F., BLACK, J., MACY, M., ROBLIN, R. Survey of cell lines in the American Type Culture Collection for Bovine viral diarrhea virus. Journal of Virological Methods, v.48, n.23, p.211-221, 1994.

5. BRAZIL. Ministry of Agriculture, Livestock and Food Supply. Governmental Directive $\mathrm{n}^{\mathrm{o}} 27,20^{\text {th }}$ of April of 2004. Disposable in: <http://sistemasweb.agricultura.gov.br/ sislegis/action/detalhaAto.do?method=abre LegislacaoFederal\&chave $=50674 \&$ tipoLeg is $=\mathrm{A}>$. Acessed on: $09^{\text {th }}$ april of 2016.

6. BOOTH, R.E., THOMAS, C.J., ELATTAR, L.M.R., GUNN, G., BROWNLIE, J. A phylogenetic analysis of Bovine Viral Diarrhoea Virus (BVDV) isolates from six different regions of the UK and links to animal movement data. Veterinary Research, v.44, n.1, p.43, 2013.

7. CARBREY, E.A., STEWART, W.C., KRESSE, J.I., SNEIDER, M.L. Natural infection of pigs with bovine viral diarrhea virus and its differential diagnosis from hog cholera. Journal of the American Veterinary Medical Association, v.169, n.11, p.1217-1219, 1976.

8. DENG, Y., SHAN, T., TONG, W., ZHENG, X.C., GUO, Y.Y., ZHENG, H. Genomic characterization of a bovine viral diarrhea virus 1 isolate from swine. Archives of Virology, v.159, n.9, p.25132517, 2014.

9. DE SMIT, A.J., EBLÉ, P.L., KLUJIVER, E.P., BLOEMRAD, M., BOUMA, A. Laboratory decision making 
during the classical swine fever eídemic of 1997-1998 in the Netherlands. Preventive Veterinary Medicine, v.42, n.3-4, p.185199, 1999.

10. DUBOVI, E.J. Laboratory diagnosis of bovine viral diarrhoea virus. Biologicals, v.41, p.8-13, 2013.

11. FLORES, E.F., WEIBLEN, R., GIL, L.H.V.G., TOBIAS, F.L., LIMA, M., GARCEZ, D.C. Diversidade antigênica de amostras do vírus da diarréia viral bovina isoladas no Brasil: implicações para o diagnóstico e estratégias de imunização. Arquivo Brasileiro de Medicina Veterinária e Zootecnia, v.52, n.1, p.11-17, 2000.

12. FLORES, E.F., RIDPATH, J., WEIBLEIN, R., VOGEL, F.S.F., GIL, L.H.V.G. Phylogenetic analysis of Brazilian bovine viral diarrhea virus type 2 (BVDV-2) isolates: evidence for a subgenotype within BVDV-2. Virus Research, v.87, n.1, p.51-60, 2002.

13. FLORES, E.F., WEIBLEIN, R., VOGEL, F.S.F., ROEHE, P.M., ALFIERI, A.A., PITUCO, E.M. A infecção pelo Vírus da Diarreia Viral Bovina (BVDV) no Brasil - histórico, situação atual e perspectivas. Pesquisa Veterinaria Brasileira, v.25, n.3, p.125-134, 2005.

14. FERNELIUS, A.L., AMTOWER, W.C., LAMBERT, G., MCLURKIN, A.W., MATTHEWS, P.J. Bovine viral diarrhoea virus in swine: characteristics of virus recovered from naturally and experimentally infected swine. Canadian Journal of Comparative Medicine, v.37, n.1, p.13, 1973.

15. JELSMA, H., LOEFFEN, W.L.A., VAN BEUNINGEN, A., VAN RIJN, P.A. Preliminary mapping of non-conserved epitopes on envelope glycoprotein E2 of
Bovine Viral Diarrhea virus types 1 and 2. Veterinary Microbiology, v.166, p.195199, 2013.

16. JENSEN, M.H. Detection of antibodies against hog cholera virus and bovine viral diarrhea virus in porcine serum. A comparative examination using CF, PLA and NPLA assays. Acta Veterinaria. Scandinavica, v.22, p.85-98, 1981.

17. LOEFFEN, W.L.A., VAN BEUNINGEN, A., QUAK, S., ELBERS, A.R.W. Seroprevalence and risk factors for the presence of ruminant Pestiviruses in the Dutch swine population. Veterinary Microbiology v.136, p. 240-245, 2009.

18. LEVINGS, R.L., WESSMAN, S.J. Bovine viral diarrhea virus contamination of nutrient serum, cell cultures and viral vaccines. Developments in biological standardization, v.75, p.177-181, 1991.

19. MOENNIG, V., LIESS, B. Ruminant Pestivirus infection in pig. Rev. sci. tech. Off. int. Epiz - OIE v.9, n.1, p.151-161, 1990.

20. OIE. World Organization for Animal Health (2016) Resolution $\mathrm{n}^{\circ} 23-$ Recognition of the Classical Swine Fever Status of Member Countries. May 2016 Paris, France.

21. O'SULLIVAN, T., FRIENDSHIP, R., CARMAN, S., PEARL, D.L., MCEWEN, B., DEWEY, C. Seroprevalence of bovine viral diarrhea virus neutralizing antibodies in finisher hogs in Ontario swine' herds and targeted diagnostic testing of 2 suspect herds. Canadian Veterinary Journal, v.52, p.1342-1344, 2011.

22. PHILIP, J.I.H., DARBYSHIRE, J.H. Infection of pigs with bovine viral diarrhea virus. Journal of comparative pathology, v.82, n.1, p.105-109, 1972. 
23. RIBEIRO, C.P. Assessment of the virus neutralization cross-reaction using BVDV-1 and BVDV-2 for diagnosing Bovina Viral Diarrhea in naturally infected animals. [Avaliação da virusneutralização cruzada frente BVDV-1 e BVDV-2 no diagnóstico da diarreia viral bovina em animais naturalmente infectados]. 2009, 80 p. Thesis (Master degree in Veterinary Medicine) - Faculty of Veterinary Medicine and Animal Science of São Paulo, University of São Paulo, São Paulo.

24. RIDPATH, J.F. Bovine Viral Diarrhea Virus: global status. Veterinary Clinics: Food Animal Practice, v.26, n.1, p.105$121,2010$.

25. SANDVIK, T. Selection and use of laboratory diagnostic assays in BVD control programmes. Preventive Veterinary Medicine, v.72, p.3-16, 2005.

26. SANTOS, A.C.R.;NASCIMENTO K.A.;MECHLER M.L.;ALMEIDA, H.M.S.,GATTO, I.R.H, CARNIELLI, L.G.F, SOUSA-POLLO, A.; DE OLIVEIRA, L.G. Experimental infection and evaluation of airborne transmission and nose-to-nose contact of bovine viral diarrhea virus among weaned piglets. Australian Journal of Basic and Applied Sciences, v.11, n.15, p.12-19, 2017.

27. STEWART, W.C., CARBREY, E.A., JENNEY, E.W., BROWN, C.L., KRESSE, J.L. Bovine viral diarrhea infection in pigs. Journal of American Veterinary Medicine Association, v.159, p.1556-1564, 1971.

28. SCHROEDER, S.;VON ROSEN, T., BLOME, S.;LOEFFEN, W.L.A.; HAEGEMAN, A., KOENNEN, F. Evaluation of Classical Swine Fever Virus antibodies assays with an emphasis on the differentiation of infected from vaccinated animals. Revue Scientifique et Technique
(International Office of Epizootics, v.31, n.3, p.997-1010, 2012.

29. TAO, J.;LIAO, J.;WANG, Y., ZHANG, X.;WANG, J.; ZHOU, G. Bovine Viral Diarrhea Virus (BVDV) infection in pigs. Veterinary Microbiology, v.165, n.34, p.185-189, 2013.

30. TERPSTRA, C.;WENSVOORT, G. Natural infections of pigs with bovine viral diarrhoea virus associated with signs resembling swine fever. Research in Veterinary Sciences, v.45, n.2, p.137-142, 1988.

31. THRUSFIELD, M.V. Veterinary Epidemiology. 3rd Ed. Blackwell Publishing, London, 2010.

32. VAN RIJN, P.A. A common neutralizing epitope on envelope glycoprotein E2 of different Pestiviruses: Implications for improvement of vaccines and diagnostics for classical swine fever (CSF)? Veterinary Microbiology, v.125, n.1-2, p. 150-156, 2007.

33. WENSVOORT, G.;TERPSTRA, C., KLUIJVER, E.P.;KRAGTEN, C., WARNAAR, J.C. Antigenic differentiation of Pestivirus strain with monoclonal antibodies against hog cholera vírus. Veterinary Microbiology, v.21, p,9-20, 1989.

34. WESSMAN, S.J.;LEVINGS, R.L. Benefits and risks due to serum used in cell culture production. Developments in Biological Standardization, v.99, p.3-8, 1999.

35. WIERINGA-JELSMA, T.;QUAK, S., LOEFFEN, W.L.A. Limited BVDV transmission and full protection against CSFV transmission in pigs experimentally infected with BVDV type $1 \mathrm{~b}$. Veterinary Microbiology, v.118, n.1-2, p.26-36, 2006. 
Almeida et al., Revista Brasileira de Higiene e Sanidade Animal (v.13, n.1) p. 1 - 14 jan - mar (2019)

36. WORLD ORGANIZATION OF ANIMAL HEALTH (OIE). 2015. Manual of diagnostic tests and vaccines for terrestrial animals. Disposable in: <http://www.oie.int/fileadmin/Home/eng/ Health_standards/tahm/2.04.08_BVD.pdf> Acessed on: 09th Apr 2016

37. XU, X.;ZHANG, Q.;YU, X.;LIANG, L.;XIAO, C.;XIANG, H. Sequence and comparative analysis of a pig Bovine viral diarrhea virus genome. Virus Research, v.122, n.1-2, p.164-170, 2000. 